\title{
Psalm 100: 'n Poëties minderwaardige en saamgeflansde teks?
}

\author{
W S Prinsloo \\ Universiteit van Pretoria
}

Abstract
Psalm 100: A poetically inferior and conflated text?

Psalm 100 is analysed on the basis of an exegetical model used by a team of researchers at the University of Pretoria. It is evident that, in spite of the contrary being maintained at times, this Psalm is a poem of the highest literary quality in which the poet uses various poetic techniques to communicate his message. He creatively uses previously known material to compose a new poem. Through the poem the 'congregation' is called upon to praise and serve Yahweh comprehensively, because he is Creator and has proved himself loving and faithful.

\section{INLEIDING}

As daar een faset van die Ou-Testamentiese wetenskap is wat die afgelope aantal jare in die middelpunt van belangstelling staan, is dit die Hebreeuse poësie. Oor die saak is daar die afgelope tyd wyd gepubliseer (vgl Prinsloo 1991:64-74 vir 'n oorsig oor die huidige stand en ontwikkeling van die navorsing in dié verband). Die belangstelling in die Hebreeuse poësie hang ook saam met wat 'n mens breedweg 'n literêre benadering tot die Ou Testament sou kon noem. Teenoor die histories-kritiese navorsing wat hoofsaaklik in die groei en in die ontstaan van 'n teks en die Sitz im Leben daarvan belangstel, word die aandag in literêre benaderings op die teks as outonome gegewene gefokus. Daar word gewys op die literêre skoonheid van die Ou-Testamentiese teks. Die voorkoms en funksie van allerlei poëtiese tegnieke in die Hebreeuse poësie word beklemtoon.

Hierdie debat vind ook weerklank aan die Universiteit van Pretoria. 'n Navorsingspan bestaande uit lede van die Departement Semitiese Tale en die Departe- 
ment Ou Testament (Afd B) is tans besig om poëtiese konvensies in die Psalms te bestudeer. ' $n$ Mens sou die benadering wat hier gevolg word, 'n komprehensiewe benadering kon noem waarin aandag aan morfologiese, sintaktiese en metriese aspekte gegee word. Van groot belang is ook die klem wat op poëtiese strategieë gelê word. Onder laasgenoemde word verskillende aspekte van klankspel, patroonvorming en semantiese aspekte gereken. Soos wat sal blyk uit die analise van Psalm 100 wat hier aangebied word, gaan dit dus om veel meer as net die ornamentele vorm. 'n Belangrike kenmerk is dat die teks in sy finale vorm as uitgangspunt geneem word.

' $n$ Verdere uitgangspunt om mee rekening te hou, is dat poëtiese tegnieke nie net dekoratief of ornamenteel van aard is nie, maar dat dit ten dienste staan van die inhoud en boodskap van die Psalm (vgl ook Berlin 1985:17).

Die analise van Psalm 100 wat hier aangebied word, is gebaseer op bogenoemde metode. Die verskillende eksegetiese fasette word hier geïntegreerd aangebied om sodoende ' $n$ gekontroleerde leesstrategie daar te stel.

Die standpunt van Sabourin (1974:183) oor Psalm 100 kan as probleemstelling dien aan die hand waarvan daar na die Psalm gekyk kan word: 'The psalm does not rank with the best from the standpoint of poetical art....'

Ten einde dié stelling van Sabourin te kan evalueer en voordat daar oorgegaan word tot ' $n$ eie analise van die Psalm, is dit egter nodig om eers kortliks aandag te gee aan die belangrikste tendense van die navorsingsgeskiedenis van Psalm 100.

\section{2. 'N KORT OORSIG VAN DIE FORSCHUNGSGESCHICHTE VAN PSALM 100}

2.1 Die wordings- en die redaksiegeskiedenis van Psalm 100

Vanuit histories-kritiese kringe is veral baie aandag aan die ontstaansgeskiedenis van die Psalm gegee. Pogings is aangewend om die sogenaamde oer- of oorspronklike teks van die Psalm te rekonstrueer. In dié proses is baie dele van die Psalm soos wat dit tans daar uitsien, as glosse of latere redaksionele byvoeginge aangedui. In hierdie verband kan Loretz (1988:374-379) en Briggs \& Briggs (1925:313) as teksboekvoorbeelde genoem word.

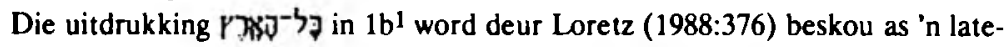
re, sekondêre uitbouing van die oorspronklike opdrag wat slegs tot die volk gerig was. Loretz (1988:374-375) meen ook dat 2a, wat deur עבדר ingelei word, oorbodig is aangesien $1 \mathrm{~b}$ reeds ' $\mathrm{n}$ werkwoord het wat 'Rufen oder Musizieren' bevat. 2a word gevolglik ook as 'n latere byvoeging beskou. Loretz gebruik veral ander Psalms (Ps $47: 2 ; 66: 1 ; 81: 2 ; 95: 1-2 ; 98: 4,6)$ as 'n kriterium om te bepaal of 2 a later bygevoeg is. Briggs \& Briggs (1925:313) oordeel dat die Godsnaam, Jahwe, in 3a dié versbeen te 
lank maak en dus onnodig is. So is Briggs \& Briggs (1925:313) ook van mening dat die הרו ('Hy') van 3b net sowel uitgelaat kan word omdat dit die reël te lank maak. Briggs \& Briggs (1925:313) argumenteer op grond van teks-gedeeltes soos Esegiël 34:31, Psalm 74:1 en 79:13 dat die 19y ('sy volk') aan die begin van 3c ook 'n glos is. Loretz (1988:377) beskou die hele vers 3 as 'n latere invoeging en hy sê deur die invoeging van dié vers word 'das Lied [d i Psalm 100] fast bis zur Unkenntlichkeit gestört'. Loretz word in sy argumentasie veral deur Crüsemann (1969:68) gelei wat van mening is dat vers 3 ('Erken dat...'), die sogenaamde Erkenntnisformel, formeel nie tuishoort by 'n himne nie. Op grond van Psalm 106:1 ('Loof die Here, want Hy is goed, want sy goedertierenheid is tot in ewigheid.', Afrikaanse Vertaling 1933/

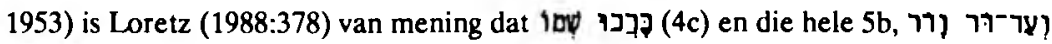
in 1 was, sekondêre byvoegings is. Ook Gunkel (1926:432) beskou 4c en 5a en 5b as 'n afwyking (Abwandlung) van die normale tôdâh-lied.

Indien daar opsommenderwys gekyk word na dié gedeeltes van Psalm 100 wat op een of ander tyd as sekondêre gedeeltes beskou is, tree die volgende prentjie na vore: Dele van 1b, 2a, die hele vers $3,4 c$ en die hele vers 5 word op een of ander stadium deur een of ander eksegeet as sekonder beskou. Indien dié redaksie-geskiedenis, soos wat dit veral deur Loretz gerekonstrueer is, ernstig opgeneem sou word, sou daar nie veel van die Psalm oorbly nie!

Die volgende samevattende opmerkings sou uit hierdie deel van die Forschungsgeschichte gemaak kon word: Die finale teks van Psalm 100 word nie altyd ernstig genoeg opgeneem deur van die histories-kritiese eksegete nie. Verder word sommige dele van die Psalm te maklik, sonder grondige redes, as sekondêr afgemaak. Soos wat sal blyk uit die komprehensiewe analise wat hier van die Psalm gemaak word, is die poëtiese tegnieke wat deur die digter van Psalm 100 aangewend is, of nie raakgesien nie df geignoreer deur diegene wat glosse of sekondêre dele aangedui het. Indien die poëtiese tegnieke werklik ernstig opgeneem is, is dit te betwyfel of die redaksionele byvoegings geidentifiseer sou gewees het. Loretz, een van diegene wat juis 'n hele aantal 'sekundäre Erweiterungen' in Psalm 100 aandui, doen dit meestal op grond van wat hy noem 'n kolometriese analise. Teen dié kolometriese analise kan daar egter ernstige kritiek ingebring word (vgl Prinsloo 1989: 471-472). Die identifisering van heelwat van die sogenaamde sekondêre dele in Psalm 100 word, soos hierbo aangetoon, gedoen op grond van die vergelyking met ander Psalms. Natuurlik is dit belangrik om Psalm 100 met ander Psalms te vergelyk. Wanneer Psalm 100 egter slegs in die lig van ander Psalms verklaar word en die Psalm gevolglik self afgeskeep word, word die selfstandigheid van die Psalm ontken en word die kreatiwiteit van die digter ook nie na waarde geskat nie. Samehangend 
hiermee kan opgemerk word dat 'n rigiede opvatting van die Gattung soms gelei het tot die identifisering van sogenaamde redaksionele byvoegings.

\section{Die Sirz in Leben van Psalm 100}

Hoewel die rekonstruksie van die kultiese en historiese agtergrond van 'n Psalm om verstaanbare redes baie belangrik is, het die bespiegeling rondom die Sitz im Leben in die geval van Psalm 100 tog die aandag van die teks van die Psalm self af weggelei. Boonop blyk uit die volgende oorsig dat die bepaling van die Sitz im Leben van Psalm 100 hoofsaaklik deur die vooronderstelling en uitgangspunt van die betrokke eksegeet bepaal word. Geen wonder dus dat die menings oor die agtergrond van Psalm 100 wyd uiteen loop nie. Dit is opvallend dat dieselfde eksegete telkens dieselfde Sitz im Leben vir elke Psalm rekonstrueer:

Soos te wagte, dui Mowinckel $(1966: 3,128,180)$ die sogenaamde troonbestygingsfees as die agtergrond aan waarteen Psalm 100 verstaan behoort te word. Terwyl daar eksegete is wat in meerdere of mindere mate by Mowinckel aansluit ${ }^{2}$, is daar egter diegene wat hulle sterk teen dié opvatting uitspreek. Gunkel \& Begrich (1933:102) gaan sover as om te sê dat die opvatting van Mowinckel volledig in die lug hang. ${ }^{3}$ Weiser (1965:645) verbind Psalm 100, soos wat hy met talle ander Psalms doen, aan die sogenaamde verbondvernuwingsfees. Daar is ook sterk ondersteuning vir die hipotese dat ons hier met met 'n prosessielied te doen het wat gesing is terwyl die aanbidders die tempel betree het (vgl bv Kittel 1922:324; Quell 1926:71; Gunkel 1926:432; Gunkel \& Begrich 1933:83; Oesterley 1939:430; Wagner 1960:439; Kraus 1966:686). Somtyds word dit spesifiek verbind aan die pelgrims uit die Diaspora (vgl bv Deissler 1979:290; Anderson 1981:698) wat die tempel nader. Teenoor dié pogings om 'n konkrete kultiese Sirz im Leben te rekonstrueer, is daar egter ook 'n opvatting dat die Psalm simbolies as 'n eskatologies-universele lied verstaan moet word. 4

Hierdie oorsig illustreer dat dit baie moeilik, indien nie onmoontlik is nie, om die oorspronklike Sitz im Leben van Psalm 100 te rekonstrueer. Hierby moet weer eens gesê word dat die rekonstruksie van die Sitz im Leben van 'n Psalm dikwels vooraf bepaal word deur die invalshoek van die bepaalde eksegeet. Dit is ook belangrik om te onderstreep dat 'n Psalm - en dit geld sekerlik ook van Psalm 100 na alle waarskynlikheid nie net een Sitz im Leben gehad het nie, maar telkens in 'n לחובה , מie (liturgiese?) opskrif van die Psalme situasie gefunksioneer het. Die ('om te loof/'vir die lofoffer') sou gebruik kon word as leidraad vir die Sitz im Leben, maar dit sou ook 'n verwysing kon wees na die Gattung van die Psalm. 


\section{Die verwantskap van Psalm 100 met ander tekste}

Dit kan nie ontken word nie dat Psalm 100 geykte taal gebruik en talle ooreenkomste met ander Ou-Testamentiese tekste - veral ander Psalms - vertoon. ${ }^{5}$ Van die opvallendste ooreenkomste is: $1 \mathrm{~b}$ met Psalm 66:1 en 98:4a; 3a met Deuteronomium 4:35, 39; 3b met Psalm 95:7; 4c met Psalm 96:2a; 5a met Psalm 106:1; 107:1; 118:1, 2a. Dit was juis dié kenmerk van Psalm 100 wat eksegete soms daartoe verlei het om nie eintlik kommentaar te lewer op die Psalm nie, aangesien hulle van mening is dat dit slegs 'n herhaling is van dit wat reeds by ander Psalms aangetref word. Sommige eksegete se kommentaar van Psalm 100 bestaan dan ook grootliks uit verwysings na ander Ou-Testamentiese tekste.

Die verwantskap van Psalm 100 tot ander Ou-Testamentiese tekste is te sterk om te ontken. Die belangrikste gevolgtrekking wat egter uit my eie analise van Psalm 100 gemaak kan word, is dat die digter op kreatiewe wyse gebruik maak van die geykte stof tot sy beskikking. Psalm 100 is dus nie ' $n$ willekeurig saamgeflansde teks nie, maar die digter span sy stof op doelbewuste en kunssinnige manier in ten einde ' $n$ nuwe teks te skep om daarmee 'n spesifieke doel te bereik. Mays (1969: 317-318) som dit korrek soos volg op:

The man who created its four lines was not only a skilled poet; he knew how to select the basic phrases of faith and culture and how to weave them together... The ianguage strikes anyone accustomed to the Old Testament as the usual sort of thing; the poem can be passed over as hardly more than an artful weaving together of the customary from the reservoir of the traditional cultic speech. But that would mistake its genius. The 'customary' words are loaded words...They are not used casually, but in a careful precision that aims at maximum significance compressed into chiseled brevity. Moreover, into the arrangement of the text, subtle but powerful variations on the expected have been wrought so as to give the four poetic lines a personality and individuality all their own.

Dié opvatting van Mays word onderstreep deur die analise van Psalm 100 wat nou volg. •

\section{3. 'N ANALISE VAN PSALM 100}

Anders as byvoorbeeld Biblia Hebraica Stuttgartensia word hier nie primêr van versreëls uitgegaan nie, maar wel van versbene. ${ }^{6}$ 


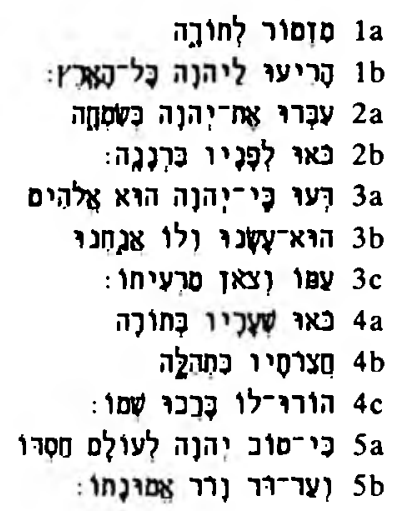

Die verhouding van die verskillende versbene op grond van morfologiese, sintaktiese, stilistiese en semantiese aspekte sou soos volg omskryf kon word:

Die eerste opvallende kenmerk is dat die eerste vier versbene $(1 b, 2 a, 2 b, 3 a)$

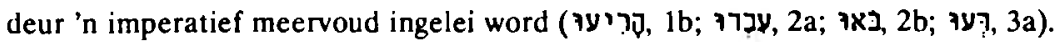
Deur die imperatiewe só te lys of aaneen te ryg, word aangetoon dat die eerste vier versbene nou verbind is en word beklemtoning ook in die hand gewerk. Assonansie word ook veroorsaak deur die herhaling van die û-klanke. Ten einde die omvatכendheid van die lof wat Jahwe toekom, na vore te bring word 'n hiperbool, ('die hele aarde') 7 in $1 \mathrm{~b}$ gebruik.

Hoewel die eerste vier versbene ( $1 b, 2 a, 2 b, 3 a)$, soos reeds aangetoon, nou verbind is, is die middelste twee versbene $(2 a, 2 b)$ om verskeie redes nog nader aan

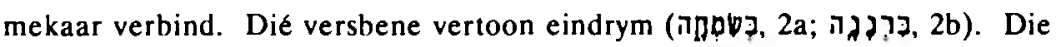
voorsetsel $\ni$ ('met') kom by beide voor. Hieruit vloei vanselfsprekend dat $2 \mathrm{a}$ en $2 \mathrm{~b}$ parallel opgebou is.

1b-3a vorm die eerste strofe van die gedig.

$3 \mathrm{~b}$ is duidelik van die voorafgaande strofe onderskeie: Eerstens word die imperatiewe onderbreek; verder is Jahwe die subjek in 3 b teenoor die voorafgaande versbene waar Hy die objek is. By wyse van die poëtiese tegniek van 'foregrounding' (vooropplasing in die sinskonstruksie) word ה הרy', d i Jahwe) sterk beklemtoon by $3 \mathrm{~b}$. Hierdie 'Hy' by $3 \mathrm{~b}$ is ' $\mathrm{n}$ heropname van dieselfde persoonlike voornaamwoord by $3 a$. By laasgenoemde versbeen is, soos reeds aangetoon, Jahwe egter die objek. In $3 a$ en $3 b$ word die stylfiguur van anadiplose aangetref deurdat die ' $\mathrm{Hy}$ ' wat in die tweede deel van $3 a$ voorkom, in die eerste deel van $3 b$ herhaal word. Dié stylfiguur lê uit die aard van die saak 'n verbintenis tussen die twee versbene. Dit is 
ook opvallend dat die eerstepersoon meervoud vir die eerste en die enigste keer in die Psalm hier by 3b gebruik word ('Hy het ons gemaak en ons is syne'8). Die rede hiervoor is waarskynlik dat juis in hierdie vers waar dit om die verhouding tussen Jahwe en sy volk handel, die eerstepersoonsvorm gebruik word om die verhouding nog meer persoonlik uit te beeld.

$3 \mathrm{~b}$ en $3 \mathrm{c}$ kan as die tweede strofe beskou word en is baie nou aan mekaar geskakel. $3 c$ is sintakties van $3 b$ afhanklik aangesien daar geen werkwoord in die eersgenoemde versbeen voorkom nie. Hierdie stylfiguur waar 'n woord weggelaat word, word 'n ellips' genoem. 'n Metafoor word in sowel $3 \mathrm{~b}$ as $3 \mathrm{c}$ gebruik om die verhouding tussen Jahwe en sy volk uit te druk: in 3 b waarskynlik die metafoor van die pottebakker (Brueggemann 1985:67) en in 3c dié van die herder. In 3c word die stylfiguur wat ek rym-inclusio wil noem, aangetref deurdat die eerste (1By) en die laaste woord (I I 1 ) van die versbeen met mekaar rym. Samehangend hiermee is die assonansie wat o-klanke betref, in $3 c$ opvallend. Indien die $Q^{\mathrm{e}}$ re-lesing i (bo die $K^{\mathrm{e}} \mathrm{tib}$-lesing) in $3 \mathrm{~b}$ aanvaar word (vgl endnota 8 ), beteken dit dat $3 \mathrm{~b}$ en $3 \mathrm{c}$ nog nader aan mekaar verbind word deur die gemeenskaplike derdepersoonenkelvoud suffikse. Hoewel $3 b-3 c$ van die voorafgaande strofe te onderskei is, is daar tog ook verbintenisse tussen die twee strofes: Naas die anadiplose tussen $3 a$ en $3 b$ waarop die aandag reeds gevestig is, word die assonansie in $\mathbf{u}$-klanke wat in die vorige stofe voorgekom het, hier in $3 \mathrm{~b}$ gekontinueer. Hoewel die motiverende 3 hier by $3 \mathrm{~b}-3 \mathrm{c}$ ontbreek (vgl 5a waar dit wel so voorkom), kan hierdie strofe beskou word as die motivering of begronding vir die oproepe tot lof en dank van die eerste strofe.

$4 \mathrm{a}$ word deur die imperatief, $7 \mathrm{~W}$, duidelik van die direk voorafgaande deel afgegrens. $4 \mathrm{a}$ lei 'n nuwe strofe, om die waarheid te sê, 'n nuwe stansa ${ }^{10}$ in. $4 a$ en $4 b$ is nou verbind, eerstens omdat $4 \mathrm{~b}$ sintakties afhanklik is van $4 a$. Die ellips-stylfiguur word weer eens gebruik (vgl bespreking by $3 \mathrm{c}$ ) aangesien daar nie 'n werkwoord by $4 \mathrm{~b}$ voorkom nie, maar slegs veronderstel word. $4 a$ en $4 b$ is om nog 'n rede verbind. Die stylfiguur van pars pro toto, naamlik dat 'n deel as verteenwoordigend van die geheel genoem word, kom by beide stiges voor. Sowel י ירץ ('sy poorte') as י ('sy voorhowe') verwys na die tempel. Laasgenoemde derdepersoonsuffikse ('sy') vềrhoog die verbintenis tussen $4 \mathrm{a}$ en $4 \mathrm{~b}$ nog meer. Verder vertoon dié twee

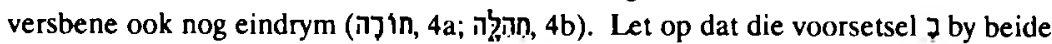
bene voorkom. As daar na al dié dinge gekyk word, dan blyk dit dat $4 a$ en $4 \mathrm{~b}$ (afgesien van die ontbrekende werkwoord by $4 \mathrm{~b}$ ) parallel opgebou is.

Die twee versvoete van $4 c$ is eweneens parallel opgebou: Albei begin met 'n im-

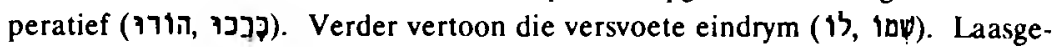
noemde derdepersoonsuffikse verwys vanselfsprekend albei na Jahwe. 
$4 a-4 b$ en $4 c$ is uit die aard van die saak nou gekoppel, aangesien meervouds-imperatiewe in dié versbene domineer. Derdepersoonsuffikse, verwysende na Jahwe, kom ook by al drie hierdie versbene voor. $4 \mathrm{a}-4 \mathrm{c}$ moet beskou word as die eerste strofe van die tweede stansa. Auffret (1983:12) wys met reg daarop dat indien die letter A gebruik word as aanduiding van die imperatief, $B$ as aanduiding van die derdepersoonsuffikse en $\mathrm{C}$ as aanduiding van die voorsetsel 7 , dan sou die verhouding van $4 \mathrm{a}, 4 \mathrm{~b}$ en die twee versvoete van $4 \mathrm{c}$ soos volg voorgestel kon word: $A B C /$ $\mathrm{BC} / \mathrm{AB} / \mathrm{AB}$.

Daar is ook opvallende ooreenkomste tusssen hierdie strofe $(4 a-4 c)$ en die eerste strofe (1b-3a). Eerstens val die rits imperatiewe by albei dele op. Veral opvallend is die herhaling van die imperatief laasgenoemde twee versbene is parallel opgebou ('Kom voor sy aangesig met gejubel//Kom [in] sy voorhowe met lof). In beide die strofes kom die voorsetsel 7 voor (kyk 2a, 2b, 4a, 4b). Verder kom daar ook afstandsrym tussen $2 a-2 b$ en $4 a-4 b$ voor in die sin dat dié vier versbene almal op 'n a-klank eindig. Deur al hierdie poëtiese tegnieke word 'n noue band tussen die twee strofes bewerkstellig.

$5 a$ en $5 b$ is om verskeie redes nou aan mekaar gebind. Anders as die voorafgaande strofe (4a-4c) ontbreek die imperatiewe hier en het ons twee nominale sinne. Die twee versbene vertoon eindrym (1700, 5a; injub 5b). In die twee versbene is daar ook ' $n$ opvallende assonansie vanweë die baie o-klanke. Semanties is daar ook 'n sterk band tussen 5 a en $5 b$, aangesien albei die versbene oor die permanente liefde en trou van Jahwe handel. Dié tema word nog meer onderstreep deur die herhaling van רור in 5b. Die waw-kopulatief aan die begin van $5 b$ versterk die band met 5 a nog meer. 5a word ingelei deur 'n motiverende 7 . Dit dui daarop dat $5 a-5 b$ as motivering geld vir die imperatiewe (die oproepe tot lof) van die voorafgaande strofe 4a-4c. Die derdepersoonsuffikse van 5a-5b (170̣,, in met dié van $4 \mathrm{c}(13$, ib). Al hierdie argumente bevestig die noue verbintenis van $5 a-5 b$ met die voorafgaande $4 a-4 c$. 5a-5b het dieselfde funksie as $3 b-3 c$ in die sin dat dit as motivering geld vir die voorafgaande imperatiewe en moet dus ook as 'n aparte strofe beskou word.

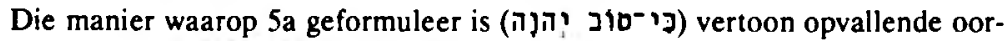

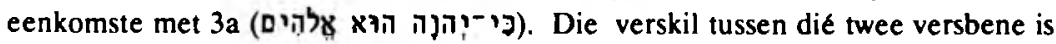
egter dat 3a deel van die imperatiewe van die eerste stansa (1b-3c) is, terwyl 5a deel van die motivering waarom Jahwe geloof moet word van die tweede stansa uitmaak. Hoewel $\urcorner$ dus in sowel $3 a$ as 5 a gebruik word, verskil die funksie van dié partikel op die twee plekke. In 3a lei dit die objeksin ná die werkwoord эฺ ị in en het dus die betekenis 'dat', terwyl dit in 5 a 'n motiverende funksie ('want') het. Deur die ooreenkomste wat daar wel tussen $3 a$ en $5 a$ bestaan, word daar egter waarskynlik 'n 
doelbewuste band gelè tussen die feit dat Jahwe as God erken moet word (3a) en die feit dat sy goedheid en liefde van permanente aard is.

Daar is ook opvallende woordherhalings in die Psalm te bespeur. Dié woordherhalings bewerk ' $n$ verdere kohesie in die Psalm: Die naam Jahwe kom vier keer in die Psalm voor (1b, 2a, 3a, 5). Daar is reeds gewys op die feit dat die imperatief 'kom' ( $7 \times$ ) wat by $2 b$ voorkom, weer by 4 a herhaal word. (1a, 4a) en dieselfde stam (ירה) kom ook weer in 4c voor (הורו (ה) Deur die woord 'n hele paar keer te herhaal, word die belangrikheid daarvan in die Psalm onderstreep. Die manier waarop die woord gebruik word, asook die parallelle opbou van $4 a-4 b$ en 4c, wys daarop dat 1 h in hierdie Psalm waarskynlik die betekenis van 'dank' of 'lof het.11 Nog 'n kenmerk van die Psalm as geheel is die talle o-klanke. Dié assonansie hang saam met die derdepersoonsuffikse wat telkens na Jahwe verwys.

Die opbou van die Psalm sou soos volg saamgevat kon word: Die Psalm bestaan uit twee stansas, naamlik $1 b-3 c$ en $4 a-5 b$. Elk van die stansas bestaan uit twee strofes, naamlik 1b-3a en 3b-3c, en 4a-4c en 5a-5b. Die twee stansas is parallel opgebou in die sin dat die eerste strofes uit imperatiewe bestaan terwyl die tweede strofes uit motiverings vir die imperatiewe geld. 12 Anders as die standpunt van Gunkel (1926:432) wat meen dat ons hier met twee himnes te doen het, bestaan Psalm 100 dus uit twee parallelle stansas waartussen daar, soos aangetoon, verskillende verbindingslyne bestaan.

\section{KONKLUDERENDE OPMERKINGS}

Hierdie analise van die Psalm bevestig dat ons met 'n gedig van hoogstaande gehalte te doen het. Die digter maak, soos aangetoon, op groot skaal van poëtiese tegnieke gebruik. Hierdie poëtiese tegnieke maak van 'n op die oog af ongekompliseerde gedig 'n kunswerk. Die standpunt dat ons met 'n minderwaardige en saamgeflansde teks te doen het, kan dus met reg afgewys word. Die verskillende poëtiese kwaliteite bewerk ' $n$ hegte kohesie in die gedig. ${ }^{13}$

Die vraag kan egter gevra word wat die digter wil kommunikeer by wyse van die gedig. Wat is die funksie van die gedig en van die poêtiese tegnieke? Sonder om hier 'n gedetailleerde eksegese aan te bied, kan die volgende grondlyne aangedui word:

- Die eerste strofe, 1b-3a, word gekenmerk deur vier imperatiewe. Deur die imperatiewe so te lys, word die hoorders opgeroep tot ware Gods-diens. Die klem val op die alomvattende lof wat Hom toekom. Hierdie oproep tot diens wat waarskynlik ook op die kultus dui, moet met die gesindheid van uitbundige blydskap en vreugde gepaard gaan. Deur die gebruikmaking van woorde soos לפק יו ('voor sy aangesig') word dit beklemtoon dat dié diens in die Here se 
teenwoordigheid moet plaasvind. Deur die herhaling van die Godsnaam en die gebruikmaking van die derdepersoonsuffikse (verwysende na Jahwe) word die volle fokus op Jahwe geplaas.

* Die vierde imperatief (ר) voer die vorige drie tot 'n hoogtepunt en onderstreep dat Gods-diens ook 'n erkenning en belydenis moet bevat, naamlik dat Jahwe (die enigste) God is. Hierdie oproep het waarskynlik 'n polemiese funksie $^{14}$ en reflekteer die politeïstiese wêreld waarin die Psalm afgespeel het.

- Die tweede strofe, $3 b-3 c$, wat ook die eerste stansa afsluit, dien as motivering vir die voorafgaande imperatiewe. Deur die gebruikmaking van twee metafore word die innige verhouding tussen Jahwe en sy 'volk' geteken. Jahwe het sy volk gemaak en daarom behoort hulle aan Hom. Hy is die Herder en sy volk is sy skape. Dit is opvallend dat partikularisme ('sy volk', 3c) en universalisme (1b, 'die hele aarde') hier hand aan hand loop (vgl ook Brueggemann 1984:165).

* Die tweede stansa, 4a-5b, is parallel aan die eerste. Dit bestaan eweneens uit imperatiewe en 'n motivering vir die imperatiewe. Inhoudelik sê dit dieselfde as die eerste stansa, maar voer die gedagtegang tog ' $n$ entjie verder. As motivering waarom Jahwe geloof moet word, word gesê dat Hy 'goed' is. Hier word verwys na sy konkrete verlossingsdade in die geskiedenis. Juis daarin kom sy רon, sy liefde, sy verbondslojaliteit tot uiting. Dit is nie iets tydeliks nie. Die liefde van Jahwe hou stand en is permanent. Israel kan hulle verlaat op die 'eeuwigdurende liefdevolle goedheid en trouw' (Van der Ploeg 1974:166) van Jahwe. Juis om dié rede moet Jahwe met vreugde gedien word.

Ons sou dus kon sê dat die funksie van die gedig oorredend van aard is. Deur gebruikmaking van 'n verskeidenheid poëtiese tegnieke word die leser of hoorder oorreed dat Jahwe lofwaardig is.

\section{ENDNOTAS}

1 Die numering van Psalm 100 wat hier gebruik word, verwys nie na die versreëls soos wat dit byvoorbeeld by Biblia Hebraica Stuttgartensia aangegee word nie, maar is gebaseer op 'n selfstandige metriese indeling in versbene.

2 Jeremias (1987:156) stel dit soos volg: 'S. Mowinckel wird mit seiner Annahme Recht haben, daß die Psalmen am Hauptfest Jerusalems, dem Herbst- und Laubhüttenfest gesungen wurden.' Hy steun Mowinckel egter nie ongekwalifi- 
seerd nie want, sê Jeremias, ons weet veel minder van dié fees as wat Mowinckel en sy navolgers wil toegee. Dahood (1986:371) sluit slegs gedeeltelik by Mowinckel aan wanneer hy opmerk: 'Though this hymn does not specifically refer to God as king, its phraseology sufficiently resembles that of the preceding psalms celebrating Yahweh's kingship....' Ringgren (1963:18) beskou Psalm 100 ook as een van die 'enthronement psalms' en Ward (1961:321) verwys ook terloops daarna as 'n troonbestygingspsalm.

3 Oesterley (1939:430) formuleer dit soos volg: 'The contention that the psalm belongs to the Enthronement group is quite beside the mark; there is nothing that suggests this.' Vergelyk ook Loretz (1988:372) wat dieselfde standpunt huldig.

4 Herkenne (1936:324) formuleer dit soos volg: 'Dieser Ps ist nicht...ein eigentliches liturgisches Prozessionslied beim Einzug in den Tempel...Wohl aber wünscht der Dichter im Bilde einer Prozession die Verwirklichung der alle Völker umfassenden Gottesgemeinde, wie sie Ps 87 für die messianische Zeit ankündet.'

5 Vir 'n volledige bespreking van dié saak, vergelyk die Psalmkommentare ad loc.

6 Oor die presiese metrum van die gedig is daar egter nie uitsluitsel nie. Kittel (1922:324), Gunkel (1926:431-432) en Kraus (1966:686) byvoorbeeld, kies vir drie tristigiese versreëls met 'n 3+3+3 metrum en 'n 4+3 metrum in die laaste versreël. Van der Lugt (1980:197) beskou Psalm 100 as die enigste Psalm wat heeltemal uit tristiges saamgestel is. Vergelyk egter Loretz (1988:378-379) vir 'n oorsig van die verskillende (tevergeefse!) pogings om die metrum van die Psalm te bepaal.

7 Dit is juis omdat eksegete nie die poëtiese tegniek van dié hiperbool in ag neem nie dat daar 'n debat ontstaan het oor hoe die uitdrukking 'die hele aarde' verstaan moet word. Gunkel (1926:432), byvoorbeeld, meen dat die uitdrukking slegs verwys na al die burgers van die land van Jahwe, terwyl Kraus (1966:687) hier aan alle lande, dus die ganse wêreld dink. Anderson (1981:698) sluit ook by Kraus aan: '[A]ll the earth rather than "all the land".' Deissler (1979:390) meen dat hier verwys word na die Diaspora-pelgrims as verteenwoordigers van die hele aarde.

8 Die Masoretiese teks van die tweede deel van 36 (נ) skep 'n tekskritiese en gevolglik ook 'n interpretasieprobleem. Die probleem sou op 'n paar maniere hanteer kon word: (i) Die $k^{\mathrm{e}}$ tîb-lesing sou behou kon word en die ver- 
taling sou dan lui, 'Hy het ons gemaak en nie onsself nie' (vgl bv König 1927: 231; Schmidt 1934:182; Herkenne 1936:325; Van der Ploeg 1974:164; Brueggemann 1985:67 wat dié moontlikheid voorstaan, asook die LXX, Symmachus en die Siriese vertaling). (ii) 'n Volgende moontlikheid is om $x$ ' te behou en dit nie as 'n negatiewe partikel te beskou nie, maar wel bevestigend of emfaties. Lewis (1967:216) wat die standpunt huldig, vertaal gevolglik: 'He has made us, and, indeed, we are his people....' Hoewel Haupt (1907:305-309) nie Psalm 100:3 as voorbeeld noem nie, voer hy tog argumente aan vir die voorkoms van die emfatiese ${ }^{\prime}$ in die Ou Testament. Haupt gebruik veral analoë gevalle in die Arabies en die Akkadies om sy argument te staaf. Vergelyk ook die bydraes van Dahood (1956:338-340), Nötscher (1953:372-380) en Loretz (1956:288-289) in hierdie verband. (iii) Whitley (1975:202-204) verteenwoordig 'n volgende moontlikheid waar die $k^{\mathrm{e}} t \hat{b} b$-lesing ook behou word, maar waar 'n kousale betekenis aan die partikel toegeken word. Whitley (1975:203) vertaal soos volg: 'He made us, and accordingly we are his people....' (iv) Die moontlikheid wat deur 'n hele paar manuskripte, Hieronimus, die Targum asook die meeste eksegete gesteun word en waarvoor ook hier gekies word (vgl Hebreeuse teks hierbo), is die $Q^{e_{r e}}$, naamlik ל ל Dertaling lui dan: 'Hy het ons gemaak en ons is syne.' Hierdie moontlikheid pas die beste by die konteks van die Psalm in. Vir 'n volledige begronding van die standpunt, vergelyk onder andere die volgende eksegete wat hulle steun daarvoor uitspreek: Wellhausen (1895:92); Duhm (1899: 236); Kirkpatrick (1903:588); Kittel (1922:324); Briggs \& Briggs (1925:313); Gunkel (1926: 432); Herkenne (1936:325); Kalt (1937:356); Buttenweiser (1938: 797); Oesterley (1939:430); Kissane (1954:136); Kraus (1966:686); Mays (1969: 315); Kidner (1975: 356-357); Deissler (1979:390); Anderson (1981:699); Auffret (1983:7, endnota 1).

9 Watson (1986:303-304) omskrywe 'ellips' met reg soos volg: 'Ellipsis is the omission of a particle, word or group of words within a poetic or grammatical unit, where its presence is expected. In other words, ellipsis is the suppression of an element demanded by the context.' Watson (1986:304-305) kies juis Psalm 100 uit as 'n voorbeeld waar die ellips op 'n groot skaal voorkom.

10 Kyk Watson (1986:160-200) vir 'n nadere beskrywing van wat met 'strofe' en 'stansa' bedoel word.

11 Koch (1961:532) wys egter met reg daarop dat die Hebreeuse woord ה 1 h sowel 'dankoffer' as 'dankpsalm' kan beteken en vir die Israeliete 'gehörte wohl beides untrennbar zusammen'. 
12 Hoewel Auffret (1983:7-14) 'n uitstekende analise van Psalm 100 gemaak het, het hy tog een belangrike aspek wat 'n invloed het op die struktuur van die Psalm, nie raakgesien nie: Auffret sê dat die Psalm uit twee parallelle dele, naamlik $1 b-3 c$ en $4 a-5$ bestaan. Sy kriterium hiervoor is twee stelle imperatiewe (volgens hom 1b-2 \& 4a-c) wat verder uitgebou word deur 17 . Wat Auffret egter nie in berekening bring nie, is dat daar by $3 c$ ook nog ' $n$ imperatief is. Verder kan die 13 by $3 a$ en by $5 a$, soos hierbo aangetoon, eenvoudig nie gelykgestel word soos wat Auffret wil doen nie. Dit blyk dus dat Auffret, soos by talle van sy ander analises, op strukturalistiese wyse te werk gaan en 'n gedwonge parallellie wil probeer bewerk deur enersyds die imperatief by $3 a$ nie in berekening te bring nie en andersyds die partikels by $3 a$ en 5 a op gelyke vlak te behandel.

13 Berlin (1989:29-30) omskryf 'kohesie' met reg soos volg: "Cohesion" as a technical term in text-linguistics, refers to the ways in which the components of the surface structure of a text - words, phrases, sentences - are linguistically connected within a sequence...Cohesion is a property of texts; it is produced by features in the text's surface structure.'

14 Brueggemann (1985:66) maak met reg die volgende opmerking oor Psalm 100: 'To praise is to reject alternative loyalties and false definitions of reality. Praise is relentlessly polemical.'

\section{Literatuurverwysings}

Anderson, A A 1981. Psalms (73-150). 2nd ed. Grand Rapids: Eerdmans. (NeCBC.)

Auffret, P 1983. Essai sur la structure littéraire du psaume 100. Biblische Notizen 20, 7-14.

Berlin, A 1985. The rhetoric of Psalm 145, in Kort, A \& Morschauser S (eds), Biblical and related studies presented to Samuel Iwry, 17-22. Winona Lake, Indiana: Eisenbrauns.

-- 1989. Lexical cohesion and biblical interpretation. Hebrew Studies 30, 29-40.

Briggs, C A \& Briggs, E G 1925. The book of Psalms. 3rd repr. Endinburgh: T \& T Clark. (ICC.)

Brueggemann, W 1984. The message of the psalms: A theological commentary. Minneapolis: Augsburg Publishing House.

-- 1985. Psalm 100. Interp. 39, 65-69.

Buttenweiser, M 1938. The Psalms. Chicago: University of Chicago Press. 
Crüsemann, F 1969. Studien zur Formgeschichte von Hymnus und Danklied in Israel. Neukirchen: Neukirchener Verlag. (WMANT 32.)

Dahood, M 1956. Enclitic mem and emphatic lamedh in Psalm 85. Bib 37, 338-340.

--- 1986. Psalms, vol II. 12th pr. New York: Doubleday. (AncB 17.)

Deissler, A 1979. Die Psalmen. 2. Aufl. Düsseldorf: Patmos.

Duhm, B 1899. Die Psalmen. Freiburg i.B.: Mohr. (KHC XIV.)

Gunkel, H 1926. Die Psalmen. 4. Aufl. Göttingen: Vandenhoeck. (HK II/2.)

Gunkel, H \& Begrich, J 1933. Einleitung in die Psalmen: Die Gattung der religiösen Lyrik Israels. Göttingen: Vandenhoeck. (HKAT II.)

Haupt, P 1907. Scriptio plena des emphatischen la- im Hebräischen. OLZ 10, 305309.

Herkenne, H 1936. Das Buch der Psalmen. Bonn: Peter Hanstein. (HSAT V/2.)

Jeremias, J 1987. Das Königtum Gottes in den Psalmen: Israels Begegnung mit dem kanaanäischen Mythos in den Jahwe-König-Psalmen. Göttingen: Vandenhoeck.

Kalt, E 1937. Die Psalmen. 2. Aufl. Freiburg i.B.: Herder. (HBK VI.)

Kidner, D 1975. Psalms 73-150. London: Intervarsity Press.

Kirkpatrick, A F 1903. Psalms. Cambridge: Cambridge University Press.

Kissane, E J 1954. The book of Psalms, vol II. Dublin: Browne \& Nolan.

Kittel, R 1922. Die Psalmen. Leipzig: Scholl. (KAT XIII.)

Koch, K 1961. 'Denn seine Güte währet ewiglich.' EvTh 21, 531-543.

König, E 1927. Die Psalmen. Gütersloh: Bertelsmann.

Kraus, H-J 1966. Psalmen, 2. Teilband. 3. unveränd. Aufl. Neukirchen: Neukirchener Verlag. (BK.AT XV/2.)

Lewis, J O 1967. An asservative $x$ in Psalm 1003. JBL 86, 216.

Loretz, O 1958. Neues Verständnis einiger Schriftstellen mit Hilfe des Ugaritischen. $B Z$ 2, 287-291.

-- 1988. Ugarit-Texte und Thronbesteigungspsalmen. Die Metamorphose des Regenspenders Baal-Jahwe. Münster: Ugarit-Verlag. (Ugaritisch-Biblische Literatur 7.)

Mays, J L 1969. Worship, world and power: An interpretation of Psalm 100. Interp. 23, 315-330.

Mowinckel, S 1966. Psalmenstudien I-II. 2. Aufl. Amsterdam: Schippers.

Nötscher, F 1953. Zum emphatischen Lamed. VT 3, 372-380.

Oesterley, W O E 1939. The Psalms, vol II. New York: Macmillan.

Prinsloo, G T M 1991. Analysing Old Testament poetry: Basic issues in contemporary exegesis. Skrif en Kerk 12/1, 64-74.

Prinsloo, W S 1989. Resensie van Loretz (1988). UF 21, 471-472. 
Quell, G 1926. Das kultische Problem der Psalmen: Versuch einer Deutung des religiösen Erlebens in der Psalmendichtung Israels. Berlin: Kohlhammer.

Ringgren, H 1963. The faith of the Psalmists. London: SCM.

Sabourin, L 1974. The Psalms. New York: Alba House.

Schmidt, H 1934. Die Psalmen. Tübingen: Mohr. (HAT 15.)

Van der Lugt, P 1980. Strofische structuren in de Bijbels-Hebreeuwse poësie. Kampen: Kok.

Van der Ploeg, J P M 1974. Psalmen II. Roermond: Romen \& Zonen. (BOT VIIb.) Wagner, N E 1960. ה ר in the Psalter. VT 10, 438-441.

Ward, J M 1961. The literary form and liturgical background of Psalm LXXXIX. VT 11, 321-339.

Watson, W G E 1986. Classical Hebrew poetry: A guide to its techniques. 2nd ed. Sheffield: The University of Sheffield Press. (JSOT SS 26.)

Weiser, A 1965. The Psalms. Transl. by H Hartwell. 3rd impr. London: SCM.

Wellhausen, J 1895. The book of Psalms: Critical edition of the Hebrew text. Leipzig: Hinrichs'sche Buchhandlung.

Whitley, C F 1975. Some remarks on lû and $l o^{\prime}$. ZAW 87, 202-204. 